\title{
Patryk Kaczmarek
}

Uniwersytet im. Adama Mickiewicza w Poznaniu

Wydziat Geografii Społeczno-Ekonomicznej i Gospodarki Przestrzennej

Zakład Studiów Regionalnych i Lokalnych

kaczy@amu.edu.pl

(D) https://orcid.org/0000-0003-0977-5454

\section{Przegląd działalności wybranych komitetów rewitalizacji w województwie wielkopolskim}

\begin{abstract}
Zarys treści: $\mathrm{W}$ artykule przedstawiono przegląd działalności czterech wybranych komitetów rewitalizacji w województwie wielkopolskim. Cztery wybrane studia przypadków reprezentują zróżnicowane pod kątem formy oraz wielkości jednostki samorządowe. Omówiono również wyniki badań Głównego Urzędu Statystycznego nad komitetami rewitalizacji działającymi w Polsce w 2017 r.
\end{abstract}

Słowa kluczowe: rewitalizacja, komitet rewitalizacji, gminny program rewitalizacji, partycypacja społeczna, Wielkopolska

\section{Wprowadzenie}

Rewitalizacja powinna być procesem całościowym uwzględniającym różne aspekty życia człowieka w przestrzeni i służącym podnoszeniu jego jakości. Proces ten ma kilka różnych definicji w literaturze przedmiotu, ale podkreśla się $\mathrm{w}$ nich wagę sfery społecznej (Parysek 2016a, b). Parysek (2016a) w swojej propozycji pryncypiów rewitalizacji podaje 9 (na 20 wymienionych), które mają społeczne powiązania. Badania nad uspołecznieniem procesu rewitalizacji podejmowane były przez wielu badaczy. Zarówno w ramach prac nad lokalnymi programami rewitalizacji (Noworól 2005, Świerczewska-Pietras 2008, Wójcicki 2010, Donderowicz i in. 2016), jak i gminnymi programami rewitalizacji (Balcerak i in. 2018, Ciesiółka 2018, Hołuj, Legutko 2018).

Komitety rewitalizacji mimo swojej krótkiej historii również podlegały analizie naukowej. Poruszana w opracowania naukowych tematyka oscylowała do tej pory wokół udziału komitetów rewitalizacji w polityce przestrzennej (Legutko-Kobus, Nowak 2020) czy głównie w partycypacji (m.in.: Tylman 2016, Przywojska 2018, Legutko-Kobus, Nowak 2020) oraz organizacji prac tych ciał (Florczyk 
2019). Niewątpliwie ważna dla badań nad komitetami rewitalizacji jest przekrojowa praca Krystek-Kucewicz i Spadło (2019). Również nad procesami rewitalizacji zachodzącymi w województwie wielkopolskim prowadzone już były badania. Zarówno pod kątem finansów (Ciesiółka 2014a, Ciesiółka, Kudłak 2015), powiązania z prowadzeniem polityki rozwoju (Ciesiółka 2014b), planowania oraz zarządzania procesem rewitalizacji (Ciesiółka 2013, 2017a, 2018, 2019, Ciesiółka, Kudłak 2015, Ciesiółka, Rogatka 2015, Ciesiółka i in. 2016, Kołsut i in. 2017), jak i kwestii społecznych w ramach tych procesów (Graczyk 2014, Jachowska 2014, Nowak 2014, Donderowicz i in. 2016) czy współpracy instytucjonalnej przy tworzeniu programów rewitalizacji (Balcerak i in. 2018), ale też stanowiły praktyczny wymiar badań naukowych w postaci założeń do gminnego programu rewitalizacji (Ciesiółka 2017b). Przykłady miast wielkopolskich prezentowały w badaniach negatywny skutek rewitalizacji, jakim jest gentryfikacja (Ciesiółka 2010, Jachowska 2014, Nowak 2018, Palicki 2018, Ciesiółka, Maćkiewicz 2020). Badania te koncentrowały się głównie na Poznaniu (Ciesiółka 2010, 2014a, b, 2017b; Nowak 2014, Ciesiółka, Rogatka 2015, Donderowicz i in. 2016, Nowak 2018, Ciesiółka, Maćkiewicz 2020), a w mniejszym stopniu na ośrodkach niższego rzędu (Graczyk 2014, Ciesiółka, Kudłak 2015, Ciesiółka i in. 2016, Ciesiółka 2017, 2018, Kołsut i in. 2017, Balcerak i in. 2018).

Celem artykułu jest omówienie działalności czterech wybranych komitetów rewitalizacji w województwie wielkopolskim oraz wyników badań nad komitetami rewitalizacji w Polsce funkcjonującymi w 2017 r. Poruszone zostały problemy rozmieszczenia i zróżnicowania wielkości. Praca ma za zadanie pogłębiać badania nad procesami rewitalizacji w województwie wielkopolskim w kontekście uspolecznienia tych zjawisk.

\section{Uspołecznienie procesu rewitalizacji i jego uwarunkowania prawne w warunkach polskich}

Współpraca zawsze przynosi wartość dodaną zarówno w odniesieniu do fazy uruchomienia, realizacji, jak i rozwijania działań (Ochojski 2014). Aktywność użytkowników i aktorów powinna być ciągłym procesem, który daje podstawy do tworzenia planów działania. Dzieje się to dzięki wykorzystywaniu przenikania mechanizmów koordynacji działań (mechanizmu rynkowego, hierarchii i mechanizmu sieciowego), różnego rodzaju struktur (partnerstwo wielopoziomowe, wielosektorowe, różne formy zaangażowania społecznego oraz aktywność sieciowa) (Ochojski 2014). Odpowiedzią na to może być governance, które w wymiarach współrządzenia i współzarządzania spełnia trzy warunki: służebność, trwałość, utylitarność (Ochojski 2014). Noworól (2005) za OECD wymienia trzy formy interakcji władzy publicznej i obywateli: informowanie, konsultowanie i aktywne uczestnictwo (jednak odpowiedzialność pozostaje nadal przy organie władzy). Udział mieszkańców w procesie tworzenia dokumentu, z którym będą się identyfikować, pozwala na jego realizację wbrew zmieniającym się kadencjom samorządu lokalnego (Balcerak i in. 2018). 
Obecnie zaangażowanie społeczne w rewitalizację regulowane jest przez dwie ustawy: ustawę o samorządzie gminnym z dnia 8 marca 1990 r. oraz ustawę o rewitalizacji z dnia 9 października 2015 r. Lokalne programy rewitalizacji oparte na ustawie z dnia 8 marca 1990 r. o samorządzie gminnym (Dz.U. z 2019 r., poz. 506) miały na celu głównie uzyskanie środków na dofinansowanie projektów (Świerczewska-Pietras 2008, Ciesiółka, Kudłak 2015) i charakter wewnętrznych ustaleń urzędników (Noworól 2005). W przypadku programów realizowanych na podstawie wspomnianej ustawy nie istniał obowiązek tworzenia komitetu rewitalizacji, jednak niektóre gminy decydowały się powoływanie ciał doradczych jako elementów partycypacji społecznej (Krystek-Kucewicz, Spadło 2019). Na podstawie przeglądu dokonanego przez Krystek-Kucewicz i Spadło (2019) można zauważyć różnorodne nazewnictwo tych organów (grupa robocza, forum, komitet, zespół, zespół zadaniowy, zespół roboczy) czy zróżnicowanie pod kątem formalizacji działań (formalne i nieformalne) oraz roli, jaką mają pełnić (m.in.: inicjowanie działań, współpraca z władzami samorządowymi, koordynacja wdrażania lokalnego programu rewitalizacji). W kontekście tej ostatniej kwestii autorki dokonują systematyzacji ciał doradczych ze względu na funkcje: opiniujące, doradcze, podejmowania własnych inicjatyw, analityczne oraz inne opcje. Organy te przestaną działać wraz z końcem 2023 r. i zakończeniem okresu przejściowego zgodnie z ustawą o rewitalizacji (Dz.U. z 2020 r. poz. 802). Proces rewitalizacji w Polsce został uporządkowany na mocy Ustawy z dnia 9 października 2015 r. o rewitalizacji. Już w drugim artykule tej ustawy podkreślony został szczególny udział mieszkańców w całym kompleksowym procesie wychodzenia ze stanu kryzysowego obszarów zdegradowanych (Dz.U. z 2020 r. poz. 802), poprzez oparcie definicji procesu na partycypacji interesariuszy (Hołuj, Legutko 2018). Ustawa przedstawia katalog narzędzi partycypacyjnych, jakimi są: konsultacje społeczne oraz prace komitetu rewitalizacji. Zakres konsultacji społecznych został przedstawiony w formie katalogu: „zbieranie uwag w postaci papierowej lub elektronicznej, w tym za pomocą środków komunikacji elektronicznej, w szczególności poczty elektronicznej lub formularzy zamieszczonych na stronie podmiotowej gminy w Biuletynie Informacji Publicznej; spotkania, debaty, warsztaty, spacery studyjne, ankiety, wywiady, wykorzystanie grup przedstawicielskich lub zbieranie uwag ustnych" (Dz.U. z 2020 r. poz. 802). Działalności komitetu rewitalizacji w obecnym modelu rewitalizacji w Polsce został poświęcony w całości art. 7 ustawy z dnia 9 października 2015 r. o rewitalizacji (Dz.U. z 2020 r. poz. 802). Ustawa wskazuje, że: „komitet rewitalizacji stanowi forum współpracy i dialogu interesariuszy z organami gminy w sprawach dotyczących przygotowania, prowadzenia i oceny rewitalizacji oraz pełni funkcję opiniodawczo-doradczą wójta, burmistrza albo prezydenta miasta". Komitet powoływany jest na drodze zarządzenia wójta, burmistrza albo prezydenta po wyznaczeniu składu na podstawie zasad określonych w uchwale rady gminy. Uchwała ta powinna zostać podjęta przed uchwaleniem gminnego programu rewitalizacji albo w terminie nie dłuższym niż trzy miesiące od jego uchwalenia. Obsługa działania komitetu należy do obowiązków organu wykonawczego w gminie. Interesującym zapisem jest wykluczenie z głosowań przedstawicieli gminy gminnych jednostek organizacyjnych w przypadku 
głosowania nad projektami dokumentów opracowanymi przez organ wykonawczy gminy lub miasta. Ustawa jednak nie wprowadza zapisów co do wielkości komitetu oraz częstotliwości jego spotkań. Przyjmując założenia „drabiny partycypacji" Arnstein (1969), można uznać, że ciało, takie jak komitet rewitalizacji jest formą działań pozorowanych, polegających na ugłaskawaniu społeczności. Udział społeczny w działaniach rewitalizacyjnych jest pozorny, stworzono model fałszywie pokazujący zaangażowanie mieszkańców w proces. Ostateczna decyzja i tak należy jedynie do władz wykonawczych i uchwałodawczych gminy. Komitet zgodnie z ustawą pełni funkcję „opiniodawczo-doradczą”, ale nigdzie nie pojawia się zobowiązanie władz do wzięcia pod uwagę tego głosu mieszkańców.

\section{Materiały źródłowe i metody badań}

W pracy zastosowano zarówno metody ilościowe, jak i jakościowe, które poprzedzone zostały przez studia literaturowe. Podstawą do przeprowadzenia badań była statystyka eksperymentalna przygotowana przez Główny Urząd Statystyczny w 2018 r., dotycząca procesu rewitalizacji na poziomie gmin. Raport został stworzony na potrzeby oceny zakresu i skali działań podejmowanych $\mathrm{w}$ gminach w ramach procesu rewitalizacji. Dane były zbierane za pomocą formularza REW „Rewitalizacja w gminie", który składał się z 10 działów tematycznych (GUS 2018). Badanie miało charakter pełny, ponieważ przeprowadzono je we wszystkich 2478 gminach w Polsce (jednak nie wszystkie gminy odesłały formularze) (GUS 2018). W przypadku czterech gmin wymagana była dodatkowa kontrola danych, dla przykładu zestaw danych GUS wykazywał m.in. trzy komitety w Bytomiu, a w rzeczywistości jest jeden zgodnie z gminnym programem rewitalizacji z $2017 \mathrm{r}$.

Zastosowana została również metoda studium przypadku (case study). Aby pogłębić badania, wybrano cztery jednostki samorządu terytorialnego, reprezentujące różne jego formy, takie jak: gmina Kleszczewo jako gmina wiejska, gmina Sompolno jako gmina miejsko-wiejska, miasto Ostrów Wielkopolski jako gmina miejska oraz miasto Kalisz jako miasto na prawach powiatu. Na podstawie ustawy z dnia 6 września 2001 r. o dostępie do informacji publicznej (Dz.U. z 2020 r. poz. 2176) autor wystąpił z prośbą o informację do czterech gmin, realizujących gminne programy rewitalizacji w województwie wielkopolskim, w zakresie:

- liczby członków komitetu rewitalizacji

- liczby zmian w składzie osobowym komitetu rewitalizacji od dnia powołania,

- liczby spotkań komitetu rewitalizacji od dnia powołania,

- frekwencji poszczególnych spotkań komitetu rewitalizacji.

Badanie zostało również przeprowadzone na podstawie szczegółowej analizy wybranych programów rewitalizacji, uchwał powołujących komitety. 


\section{Komitety rewitalizacji w Polsce w 2017 r.}

W 2017 r. w Polsce funkcjonowało 238 komitetów rewitalizacji powołanych na podstawie ustawy o rewitalizacji (na 309 gmin dysponujących gminnym programem rewitalizacji) mających 2864 członków (GUS 2018) (ryc. 1). W tej liczbie prawie wszystkie gminy prócz miasta Gorzowa Wielkopolskiego posiadały po jednym komitecie. Największe nagromadzenie działających komitetów widoczne było w województwie małopolskim.

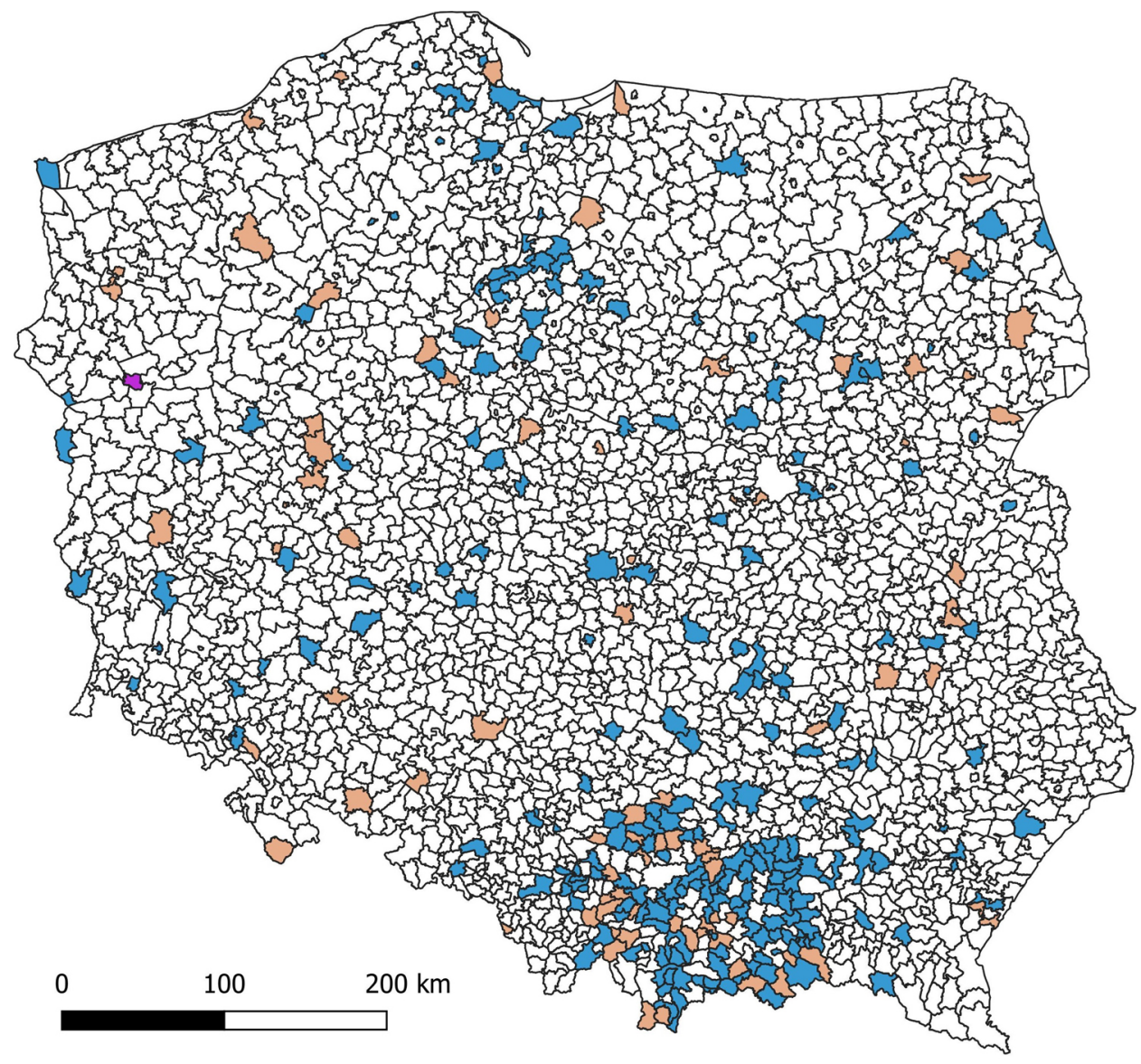

Liczba funkcjonujących komitetów rewitalizacji lub innych organów w 2017 roku

$\square$ brak powołanego komitetu rewitalizacji lub innego organu w 2017 roku

$\square 1$

$\square 3$

$\square$ gminy

Ryc. 1. Istniejące komitety rewitalizacji w Polsce w 2017 r.

Źródło: opracowanie własne na podstawie GUS (2018). 
Zgodnie z danymi dostępnymi w opracowaniu Głównego Urzędu Statystycznego część gmin w 2017 r. nie wybrała bądź nie wyznaczyła komitetów rewitalizacji lub innych organów uspołeczniających proces rewitalizacji (ryc. 2). Największy komitet znajdował się w Skawinie i liczył 41 członków, najmniejszy w Grzegorzewie, gdzie w jego skład powołane zostały 3 osoby (GUS 2018). Srednia wielkość komitetu w 2017 r. wynosiła 13 osób, a mediana liczby członków 10 osób. To zróżnicowanie, całkowicie niezależne od wielkości obszaru rewitalizacji czy

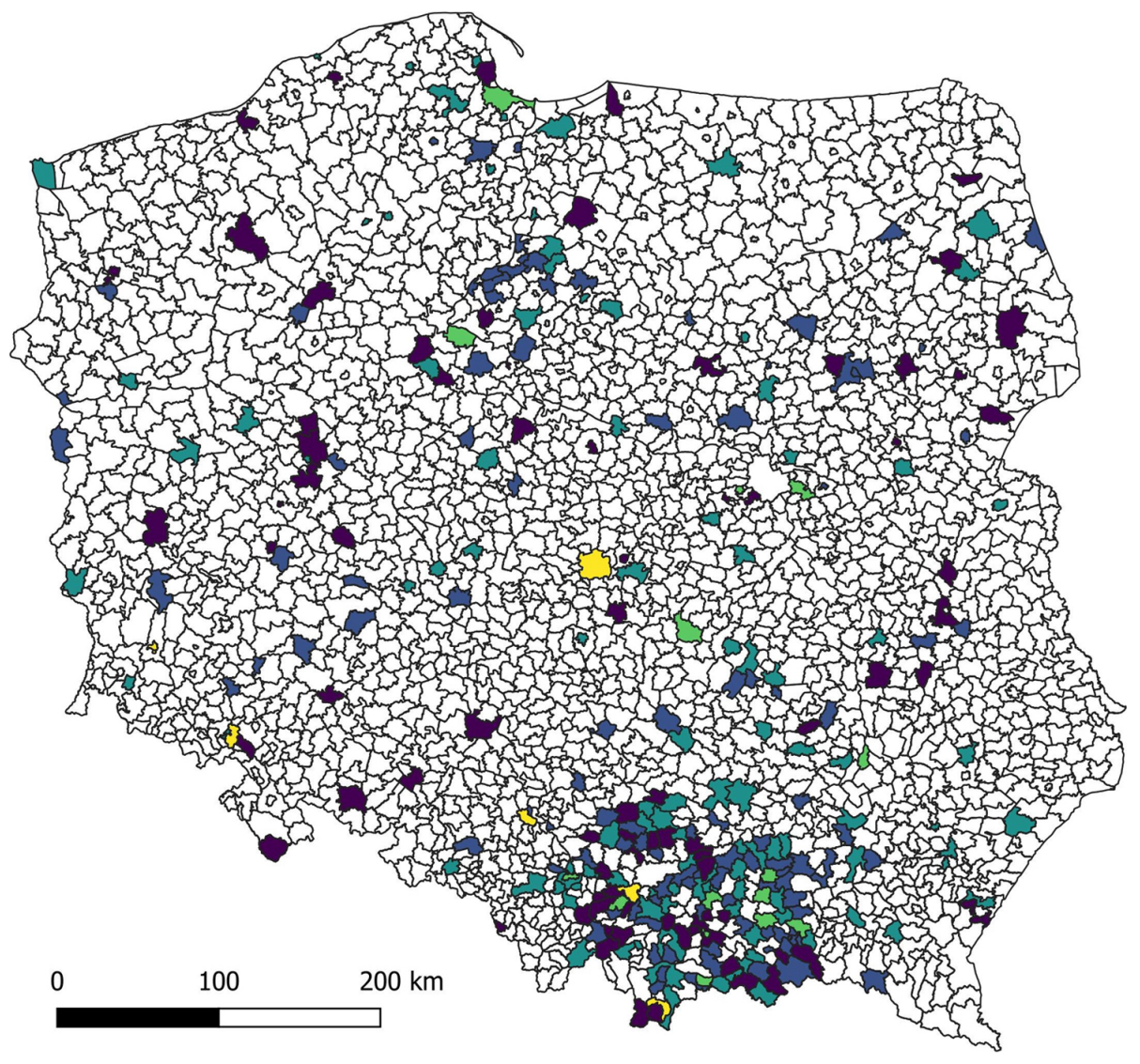

Liczba członków komitetu rewitalizacji lub innych organów w gminach w 2017 roku

brak powołanego Komitetu Rewitalizacji lub innego organu w 2017 roku

$\square$ mniej niż 10 członków

$\square$ 10-20 członków

20-30 członków

więcej niż 30 członków

gminy

Ryc. 2. Zróżnicowanie wielkości komitetów rewitalizacji w Polsce w 2017 r.

Źródło: opracowanie własne na podstawie GUS (2018). 
liczby ludności zamieszkującej ten obszar, wynika z braku wytycznych w ustawie o rewitalizacji.

\section{Komitety rewitalizacji w województwie wielkopolskim - studia przypadków}

Na potrzeby studium przypadku wybrano cztery gminy z województwa wielkopolskiego: gmina Kleszczewo jako gminę wiejską, gminę Sompolno jako gminę miejsko-wiejską, miasto Ostrów Wielkopolski jako gminę miejską oraz miasto Kalisz jako miasto na prawach powiatu (ryc. 3).

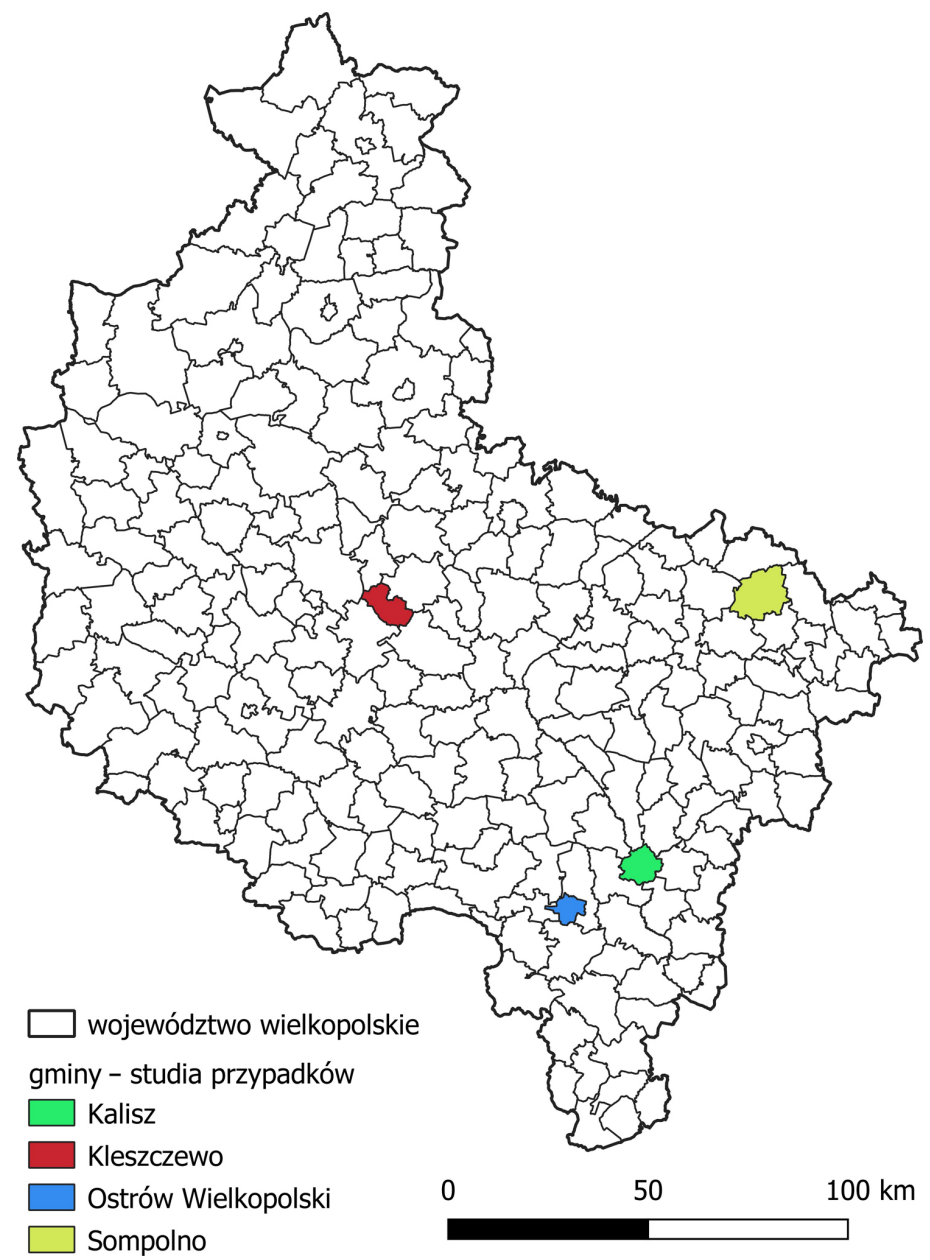

Ryc. 3. Lokalizacja omawianych przykładów w województwie wielkopolskim Źródło: opracowanie własne. 
Największym badanym miastem jest Kalisz (tab. 1), który w 2017 r. zamieszkiwało 101625 mieszkańców, a obszar rewitalizacji wyznaczony na podstawie gminnego programu rewitalizacji 18027 (17,78\% mieszkańców miasta). Drugim w kolejności miastem jest Ostrów Wielkopolski zamieszkiwany w 2017 r. przez 72364 mieszkańców, z czego 16798 (23,21\%) zamieszkiwało obszar rewitalizacji. Gminę miejsko-wiejską Sompolno zamieszkiwało 10414 osób, z czego 1971 $(18,92 \%)$ w rejonie wyznaczonym jako obszar rewitalizacji. Najmniejszym przykładem jest gmina wiejska Kleszczewo zamieszkiwana przez 7998 mieszkańców, z których 711 mieszkało na obszarze rewitalizacji $(8,88 \%)$.

Tabela 1. Omawiane przykłady gmin

\begin{tabular}{llccc}
\hline \multicolumn{1}{c}{ Gmina } & Rodzaj gminy & $\begin{array}{c}\text { Liczba mieszkań- } \\
\text { ców (2017) }\end{array}$ & $\begin{array}{c}\text { Liczba mieszkańców } \\
\text { zamieszkujących obszar } \\
\text { rewitalizacji (2017) }\end{array}$ & $\begin{array}{c}\text { Liczba członków } \\
\text { komitetu rewitali- } \\
\text { zacji (2020) }\end{array}$ \\
\hline Kleszczewo & $\begin{array}{l}\text { gmina wiejska } \\
\text { gmina miejsko- }\end{array}$ & 7998 & 711 & 7 \\
Sompolno & $\begin{array}{l}\text {-wiejska } \\
\text { Ostrów Wiel- }\end{array}$ & 70414 & 1971 & 20 \\
kmina miejska & 72364 & 16798 & 13 \\
Kalisz & $\begin{array}{l}\text { miasto na pra- } \\
\text { wach powiatu }\end{array}$ & 101625 & 18027 & $15^{*}$ \\
\hline
\end{tabular}

*Skład w Kaliszu nie był w całości obsadzony i od czasu powołania nastąpiło kilka zmian w jego składzie, a pierwotna liczba wynosi 20 osób.

Źródło: opracowanie własne na podstawie GUS 2018 oraz https://bdl.stat.gov.pl/.

Największe komitety zostały powołane w Sompolnie i Kaliszu (kaliski komitet nie działa w pełnym składzie).

„Gminny Program Rewitalizacji dla Gminy Kleszczewo” został przyjęty przez radę gminy Kleszczewo 28 czerwca 2017 r. $^{1}$ Zarządzeniem wójta gminy Kleszczewo $z$ dnia 28 września 2017 r. powołano Komitet w składzie 7 osób ${ }^{2}: 2$ przedstawicieli mieszkańców gminy Kleszczewo, 2 przedstawicieli rady gminy Kleszczewo, 1 przedstawiciel organizacji pozarządowych oraz 1 reprezentujący „środowisko oświaty, kultury i służby zdrowia”, 1 przedstawiciel „pozostałej grupy interesariuszy". Na podstawie informacji uzyskanej w lutym 2020 r. można stwierdzić, że nie doszło do zmian w składzie osobowym komitetu, a od dnia powołania odbyło się tylko jedno spotkanie, na którym byli wszyscy członkowie komitetu. Komitet nie ma (kwiecień, wrzesień) swojej podstrony na stronie internetowej Urzędu Gminy ani w „Biuletynie Informacji Publicznej Gminy Kleszczewo”.

„Gminny Program Rewitalizacji dla Gminy Sompolno" został przyjęty przez radę gminy Sompolno 25 sierpnia 2017 r. $^{3}$ W uchwale w sprawie zasad wyzna-

Uchwała nr XXXII/222/2017 Rady Gminy Kleszczewo z dnia 28 czerwca 2017 r.

2 Zarządzenie nr 58/2017 Wójta Gminy Kleszczewo z dnia 28 września 2017 r. w sprawie powołania Komitetu Rewitalizacji.

3 Uchwała nr XXXIX/272/2017 Rady Miejskiej w Sompolnie z dnia 25 sierpnia 2017 r. w sprawie przyjęcia Gminnego Programu Rewitalizacji dla Gminy Sompolno wraz z załącznikiem „Gminny Program Rewitalizacji dla Gminy Sompolno". 
czania komitetu wskazano, że organ ten może liczyć nie więcej niż 25 członków ${ }^{4}$. Również zaznaczono, że w składzie komitetu może być nie więcej niż 2 przedstawicieli środowiska oświaty, kultury i służby zdrowia, 2 przedstawicieli rady gminy Sompolno, 2 przedstawicieli środowiska architektów, urbanistów i planistów przestrzennych, nie więcej niż 13 mieszkańców gminy, 2 przedstawicieli środowiska gospodarczego, 2 przedstawicieli organizacji pozarządowych działających na obszarze gminy Sompolno oraz nie więcej niż 2 przedstawicieli pozostałych grup interesariuszy niewymienionych w innych podgrupach. W informacji otrzymanej od urzędu w Sompolnie gmina deklaruje, że nie było zmian w składzie komitetu (20 osób) od dnia powołania oraz że odbyły się dwa spotkania - na pierwszym frekwencja wyniosła $100 \%$, a na drugim $75 \%$.

Rada miejska Ostrowa Wielkopolskiego przyjęła program rewitalizacji 31 maja 2017 r. ${ }^{5} 31$ stycznia 2017 r. prezydent Ostrowa Wielkopolskiego powołał komitet rewitalizacji w składzie 13 osób $^{6}$. Wcześniejsza uchwała dotycząca zasad wyznaczania składu komitetu nie reguluje liczby reprezentantów poszczególnych grup interesariuszy ${ }^{7}$. Powołany komitet (wrzesień 2020) ma podstronę internetową, na której można sprawdzić jego skład ${ }^{8}$ Urząd Ostrowa Wielkopolskiego w odpowiedzi na pismo z prośbą o informację publiczną stwierdził, że w komitecie nie zostały dokonane zmiany, a odbyło się 9 spotkań, na których średnia frekwencja wyniosła $65 \%$.

Kaliski gminny program rewitalizacji został uchwalony uchwałą rady miasta Kalisza dnia 27 lipca 2017 r. ${ }^{9}$ Zarządzeniem prezydenta Kalisza w skład komitetu weszło 20 osób $^{10}: 2$ przedstawicieli Urzędu Miasta, 2 radnych miejskich, 2 przedstawicieli rad osiedlowych, 1 przedstawiciel organów władzy publicznej (Skarb Państwa, administracja rządowa), 2 przedstawicieli podmiotów społecznych, 1 przedstawiciel podmiotów gospodarczych, 3 przedstawicieli właścicieli nieruchomości lub użytkowników wieczystych, 5 mieszkańców z obszaru rewitalizacji oraz 2 przedstawicieli mieszkańców spoza obszaru rewitalizacji. W składzie komitetu rewitalizacji w Kaliszu, według informacji uzyskanych z Urzędu Miasta Kalisza, dokonano łącznie 5 zmian, a obecnie (2020) nieobsadzone jest 5 miejsc. Komitet rewitalizacji w Kaliszu jest najbardziej aktywny wśród zbadanych w tym artykule, od jego powołania w 2017 r. odbyło się 13 spotkań. Średnia frekwencja wyniosła prawie $69 \%$.

4 Uchwała nr XXXIX/273/2017 Rady Miejskiej w Sompolnie z dnia 25 sierpnia 2017 r. w sprawie zasad wyznaczania składu oraz zasad działania Komitetu Rewitalizacji.

5 Uchwała nr XXXIV/399/2017 Rady Miejskiej Ostrowa Wielkopolskiego z dnia 31 maja 2017 r. w sprawie przyjęcia Programu Rewitalizacji dla Ostrowa Wielkopolskiego na lata 2016-2023.

6 Zarządzenie nr 1637/VII/2017 Prezydenta Miasta Ostrowa Wielkopolskiego z dnia 31.01.2017 r.

7 Uchwała nr XXVI/312/2016 Rady Miejskiej Ostrowa Wielkopolskiego z dnia 27 października $2016 \mathrm{r}$.

8 https://umostrow.pl/ostrowski-komitet-rewitalizacji.html (data dostępu: 23.09.2020).

9 Uchwała nr XLI/512/2017 Rady Miejskiej Kalisza z dnia 27 lipca 2017 r. w sprawie przyjęcia Gminnego Programu Rewitalizacji Miasta Kalisza.

10 Zarządzenie nr 43/2017 Prezydenta Miasta Kalisza z dnia 17 stycznia 2017 r. w sprawie powołania Komitetu Rewitalizacji Miasta Kalisza. 


\section{Podsumowanie i rekomendacje}

Komitet rewitalizacji pozwala zgodnie $z$ ustawowymi zapisami na współzarządzanie oraz partnerstwo wielosektorowe, będąc jednocześnie aktywną formą interakcji władzy publicznej i obywateli, jest również szansą na trwałość procesu rewitalizacji bez względu na kadencyjność samorządu. Zakończenie obowiązywania programów rewitalizacji na podstawie ustawy o samorządzie gminnym jest szansą na poprawę zapisów dotyczących funkcjonowania komitetów rewitalizacji (które staną się obligatoryjnym sposobem partycypacji społecznej w procesach rewitalizacyjnych), ponieważ obecna rola komitetów jako organów opiniodawczo-doradczych jest pozorna - brak obowiązku uwzględniania uwag przez organy samorządowe.

Widoczny jest w studiach przypadków brak ogólnych wytycznych co do liczebności komitetu i jego reprezentatywności. Miasto Kalisz i Sompolno pierwotnie miały dwudziestoosobowe komitety, przy czym w Kaliszu obszar rewitalizacji zamieszkuje kilkakrotnie więcej mieszkańców. W skali kraju na podstawie statystyk GUS również widoczne jest duże zróżnicowanie liczebnościowe komitetów niepowiązane z liczbą mieszkańców. Wskazywany w części przypadków brak zmian w składach komitetów wskazuje na kolejny problem, jakim jest nieokreślona kadencyjność. Ze względu na małą aktywność dwóch badanych komitetów należy postawić pytanie o faktyczną chęć zaangażowania mieszkańców w proces odnowy. Inne dociekania wobec roli komitetów rewitalizacji w programowaniu rewitalizacji powinny dotyczyć kwestii osobistych doświadczeń członków komitetów (w tym powodów chęci angażowania się), działalności Komitetów w kontekście oceny i monitorowania projektów rewitalizacyjnych. Mimo braku sprecyzowania kwestii funkcjonowania komitetów rewitalizacji niewątpliwie na plus należy ocenić uporządkowanie partycypacji społecznej w rewitalizacji.

Problemem jest też brak danych zbieranych w skali kraju dotyczących Komitetów rewitalizacji. Istniejące i użyte $\mathrm{w}$ artykule zestawienie pochodzące $z$ GUS ma charakter jednostkowy. Należałoby oddzielić w statystykach ustawowe komitety rewitalizacji od pozostałych organów opiniodawczo-doradczych. Na pewno na potrzeby badań bardzo pomocne byłoby coroczne raportowanie przez gminy do Głównego Urzędu Statystycznego informacji o gminnych programach rewitalizacji i lokalnych programach rewitalizacji.

\section{Literatura}

Arnstein S.R. 1969. A Ladder of Citizen Participation. Journal of the American Planning Association, 35: 4, 216-224.

Balcerak M., Główczyński M., Wronkowski A. 2018. Dobre praktyki przy tworzeniu Gminnego Programu Rewitalizacji - efekt współpracy Uniwersytetu im. Adama Mickiewicza z Miastem Kaliszem. Biuletyn KPZK PAN, 270: 41-53.

Ciesiółka P. 2010. Zjawisko gentryfikacji na obszarach Miejskiego Programu Rewitalizacji dla Miasta Poznania. [W:] E. Grzelak-Kostulska, B. Hołowiecka (red.), Zmiany obszarów miejskich i wiej- 
skich w świetle wybranych analiz demograficznych i funkcjonalno-przestrzennych. Wydawnictwo Naukowe Uniwersytetu im. M. Kopernika, Toruń, s. 99-112.

Ciesiółka P. 2013. Proces rewitalizacji miast i gmin aglomeracji poznańskiej. Planowanie i zarządzanie. Bogucki Wydawnictwo Naukowe, Poznań.

Ciesiółka P. 2014a. Wpływ funduszy Unii Europejskiej na proces rewitalizacji w Poznaniu na tle największych miast w Polsce. Rozwój Regionalny i Polityka Regionalna, 27: 101-121 (https://doi. org/10.14746/rrpr.2014.27.07).

Ciesiółka P. 2014b. Rewitalizacja jako element polityki rozwoju aglomeracji poznańskiej. Problemy Rozwoju Miast, 2: 17-30.

Ciesiółka P. 2017a. Delimitacja obszaru zdegradowanego i obszaru rewitalizacji - doświadczenia miast województwa wielkopolskiego. [W:] W. Ratajczak, M. Szewczyk, J. Weltrowska (red.), Teoretyczne i praktyczne aspekty prawa gospodarki przestrzennej. Bogucki Wydawnictwo Naukowe, Poznań, s. 211-224.

Ciesiółka P. (red.) 2017b. Uwarunkowania i kierunki działań rewitalizacyjnych w Poznaniu. Bogucki Wydawnictwo Naukowe, Poznań.

Ciesiółka P. 2018. Doświadczenia miast subregionalnych w programowaniu rewitalizacji. Biuletyn KPZK PAN, 270: 7-23.

Ciesiółka P. 2019. Systemy monitorowania rewitalizacji w gminach województwa wielkopolskiego Rozwój Regionalny i Polityka Regionalna, 48: 23-39.

Ciesiółka P., Kołsut B., Kudłak R. 2016. Programowanie rewitalizacji w miastach województwa wielkopolskiego w latach 1999-2015. Rozwój Regionalny i Polityka Regionalna, 36: 57-71.

Ciesiółka P., Kudłak R. (red.) 2015. Diagnoza rewitalizacji miast w województwie wielkopolskim. Wielkopolskie Regionalne Obserwatorium Terytorialne, Poznań.

Ciesiółka P., Maćkiewicz B. 2020. From regeneration to gentrification: Insights from a Polish city. People, Place and Policy, 14: 199-215 (https://doi.org/10.3351/ppp.2020.2955385256).

Ciesiółka P., Rogatka K. 2015. Rola miejscowych planów zagospodarowania przestrzennego w procesie rewitalizacji miast na przykładzie metropolii Poznań. Problemy Rozwoju Miast, 4/2015: $27-36$.

Dane statystyczne z zakresu rewitalizacji na poziomie gmin 2018. Główny Urząd Statystyczny. Warszawa.

Donderowicz M., Główczyński M., Wronkowski A. 2016. Partycypacja społeczna w rewitalizacji - rola stowarzyszeń lokalnych na przykładzie Poznania. Problemy Rozwoju Miast, IV: 41-51.

Florczyk R. 2019. Organizacja formalnych sposobów uspołecznienia przy wdrażaniu programów rewitalizacji - przypadki wybranych gmin Obszaru Metropolitalnego Warszawy. Prace i Studia Geograficzne, 3: 93-109.

Graczyk R. 2014. Wybrane aspekty społeczne i komercyjne rewitalizacji małych miast Wielkopolski. [W:] R.A. Macyra (red.), Nowe życie w mieście? Dylematy rewitalizacji. Wydawnictwo Naukowe Wydziału Nauk Społecznych UAM, Poznań, s. 71-88.

https://bdl.stat.gov.pl/ (dostęp: 23.09.2020).

https://umostrow.pl/ostrowski-komitet-rewitalizacji.html (dostęp: 23.09.2020).

Hołuj D., Legutko-Kobus P. 2018. Partycypacja jako element rewitalizacji. (Przykłady miast z województwa małopolskiego i mazowieckiego). Studia Ekonomiczne, 365: 93-119.

Jachowska J. 2014. Łazarz - o społecznych skutkach gentryfikacji. [W:] R.A. Macyra (red.), Nowe życie w mieście? Dylematy rewitalizacji. Wydawnictwo Naukowe Wydziału Nauk Społecznych UAM, Poznań, s. 71-88.

Kołsut B., Ciesiółka P., Kudłak R. 2017. Działania rewitalizacyjne w miastach województwa wielkopolskiego w latach 1999-2015 oraz ich efekty. Studia Regionalne i Lokalne, 2: 50-68.

Krystek-Kucewicz B., Spadło K. 2019. Komitety rewitalizacji w praktyce. Raport z analizy funkcjonowania komitetów rewitalizacji w miastach biorących udział w konkursie dotacji „Modelowa Rewitalizacja Miast” oraz realizujących projekty pilotażowe w rewitalizacji. Instytut Rozwoju Miast i Regionów, Warszawa.

Legutko-Kobus P., Nowak M.J. 2020. Niesprawność władz publicznych w świetle prawno-przestrzennych i partycypacyjnych narzędzi rewitalizacji. Studia z Polityki Publicznej, 3: 117-135.

Nowak M. 2014. Sródka po siedmiu latach rewitalizacji. Metateoretyczny wtręt i interpretacja socjologii procesu ożywiania miasta. [W:] R.A. Macyra (red.), Nowe życie w mieście? Dylematy rewitalizacji. Wydawnictwo Naukowe Wydziału Nauk Społecznych UAM, Poznań, s. 49-70. 
Nowak M. 2018. Niezrealizowana rewitalizacja jako niedoskonała gentryfikacja. Analiza procesu ożywiania poznańskiej Śródki. Ruch Prawniczy, Ekonomiczny i Socjologiczny, 75(3): 229-249 (https://doi.org/10.14746/rpeis.2013.75.3.16).

Noworól K. 2005. Uczestnictwo publiczne i konsultacje społeczne w lokalnych programach rewitalizacji. Zarządzanie Publiczne, 1: 81-92.

Ochojski A. 2014. Współrządzenie i współzarządzanie w rozwoju lokalnym. [W:] A. Klasik, F. Kuźnik (red.), Miasta - metropolie - regiony. Nowe orientacje rozwojowe. Wydawnictwo Uniwersytetu Ekonomicznego w Katowicach, Katowice, s. 219-236.

Palicki S. 2018. Rewitalizacja a rynek nieruchomości mieszkaniowych. Przypadek poznańskiej Śródki. Ruch Prawniczy, Ekonomiczny i Socjologiczny, 75: 209-228 (https://doi.org/10.14746/rpeis. 2013.75.3.15).

Parysek J.J. 2016a. O najbliższej przyszłości rewitalizacji w Polsce: pragmatycznie i prognostycznie. Problemy Rozwoju Miast, IV: 5-17.

Parysek J.J. 2016b. Rewitalizacja jako problem i zadanie własne polskich samorządów lokalnych. Rozwój Regionalny i Polityka Regionalna, 33: 17-35.

Program Rewitalizacji dla Gminy Kleszczewo (http://bip.kleszczewo.pl/?p=document\&action=show\&id=13811\&bar_id=6800; dostęp: 21.04.2020).

Przywojska J. 2018. Organizacyjno-prawne uwarunkowania partycypacji społecznej w rewitalizacji gmin. Opinie i Analizy, 34: 1-18.

Świerczewska-Pietras K. 2008. Lokalne programy rewitalizacji w kształtowaniu przestrzeni miejskiej na przykładzie Krakowa i Poznania. Państwo i Społeczeństwo, 3: 93-100.

Tylman A. 2016. Partycypacja społeczna w finansowaniu procesów miejskich na przykładzie rewitalizacji. Przedsiębiorczość i Zarządzanie, 8.3: 281-292.

Uchwała nr XXXIV/399/2017 Rady Miejskiej Ostrowa Wielkopolskiego z dnia 31 maja 2017 r. w sprawie przyjęcia Programu Rewitalizacji dla Ostrowa Wielkopolskiego na lata 2016-2023.

Uchwała nr XXXII/222/2017 Rady Gminy Kleszczewo z dnia 28 czerwca 2017 r.

Uchwała nr XXXIX/272/2017 Rady Miejskiej w Sompolnie z dnia 25 sierpnia 2017 r. w sprawie przyjęcia Gminnego Programu Rewitalizacji dla Gminy Sompolno wraz z załącznikiem „Gminny Program Rewitalizacji dla Gminy Sompolno".

Uchwała nr XXXIX/273/2017 Rady Miejskiej w Sompolnie z dnia 25 sierpnia 2017 r. w sprawie zasad wyznaczania składu oraz zasad działania Komitetu Rewitalizacji.

Uchwała nr XXVI/312/2016 Rady Miejskiej Ostrowa Wielkopolskiego z dnia 27 października 2016 r.

Uchwała nr XLI/512/2017 Rady Miejskiej Kalisza z dnia 27 lipca 2017 r. w sprawie przyjęcia Gminnego Programu Rewitalizacji Miasta Kalisza.

Ustawa z dnia 8 marca 1990 r. o samorządzie gminnym (Dz.U. z 2019 r., poz. 506).

Ustawa z dnia 9 października 2015 r. o rewitalizacji (Dz.U. z 2020 r., poz. 802).

Ustawa z dnia 6 września 2001 r. o dostępie do informacji publicznej (Dz.U. z 2020 r., poz. 2176).

Wójcicki M. 2010. Miejski Program Rewitalizacji dla miasta Poznania i dzielnicy Śródka - przykład uspołecznionego modelu odnowy miasta. Rozwój Regionalny i Polityka Regionalna, 12: 97-117.

Zarządzenie nr 58/2017 Wójta Gminy Kleszczewo z dnia 28 września 2017 r. w sprawie powołania Komitetu Rewitalizacji.

Zarządzenie nr 1637/VII/2017 Prezydenta Miasta Ostrowa Wielkopolskiego z dnia 31.01.2017 r.

Zarządzenie nr 43/ 2017 Prezydenta Miasta Kalisza z dnia 17 stycznia 2017 r. w sprawie powołania Komitetu Rewitalizacji Miasta Kalisza.

\title{
Review of the activity of selected revitalisation committees in Wielkopolskie voivodeship
}

\begin{abstract}
The article presents a review of the activities of four selected revitalisation committees in Wielkopolskie voivodeship. The four case studies selected represent local government units varying in form and size. The results of the Central Statistical Office's research on revitalization committees operating in Poland in 2017 were also discussed.
\end{abstract}

Key words: revitalization, revitalization committee, municipal revitalization program, social participation, Wielkopolska 